\title{
BIMBINGAN KELOMPOK DENGAN TEKNIK PERMAINAN TRADISIONAL UNTUK MENINGKATKAN PENYESUAIAN SOSIAL
}

\author{
Dinar Mahdalena Leksana \\ Program Studi PIAUD, Fakultas Agama Islam, Universitas Islam Lamongan \\ Jl.Veteran No. 53 A Lamongan 62213 \\ Telp. 0322-324706/0856-5403-6632 \\ E-mail: chealeksa.ca@gmail.com
}

\begin{abstract}
This study aims to: (1) determine the implementation of group guidance and the level of social adjustment of grade 1 students at SDN Kedondong 01, (2) determine the effectiveness of group guidance with traditional games in improving students' social adjustment. This study is a quantitative study using a pre-test post-test one group design. The data analysis technique used is Wilcoxon's Signed Rank Test which is classified as nonparametric statistics. Based on the significance level of 5\% and data analysis $N=8$ shows the difference in scores between before and after the implementation of group guidance with traditional game techniques. The results of the field test show that the group guidance model with traditional learning techniques is effective in improving the social adjustment of first grade students at SDN Kedondong 01. This is indicated by the changes in the level of social adjustment of students before and after implementation. . which is an average increase of 38\%. Therefore, it is recommended for classroom teachers as counselors in elementary schools to be able to take advantage of group guidance with traditional game techniques as an effort to improve students' social adjustment.

Keywords: Social Adjustment, Group Guidance, Traditional Games
\end{abstract}

\section{Pendahuluan}

Dilihat dari usia perkembangannya, usia Sekolah Dasar (SD) disebut juga masa intelektual, yaitu masa kerukunan di sekolah pada usia 6-7 tahun, anak dianggap dewasa untuk masuk sekolah. Periode usia sekolah dasar dibagi menjadi dua, yaitu: (a) periode kelas bawah dan (b) periode kelas atas. Anakanak yang bersekolah di tahun-tahun pertama sekolah dasar adalah anak-anak yang termasuk dalam kelompok usia pertama. Anak usia dini merupakan masa yang singkat dari perkembangan seorang anak, tetapi merupakan masa yang sangat penting dalam hidupnya. Oleh karena itu, saat ini segala potensi yang dimiliki anak harus didorong agar berkembang secara optimal.

Kegiatan (Bimbingan dan Konseling) BK di SD dinilai baik untuk dilakukan. Ini dikarenakan pada jenjang pendidikan ini, anak harus bisa bersosialisasi dan belajar secara formal. Kegiatan BK di SD dapat membantu peserta didik dalam mengatasi masalah yang mungkin muncul pada kehidupannya. Bantuan tersebut paling tepat untuk peserta didik di sekolah, agar peserta didik mampu mencapai tugas perkembangan yang maksimal untuk dirinya yang meliputi aspek kepribadian, sosial, belajar dan karir. Bimbingan di SD memiliki ciri tersendiri, yaitu: (1) Di SD tidak memiliki tenaga ahli/petugas khusus BK (2) Guru kelas juga bertindak sebagai guru pembimbing; (3) fokus pelaksanaan bimbingan di sekolah dasar pada pengembangan pemahaman diri, pemecahan masalah dan kemampuan berhubungan 
secara efektif dengan orang lain; (4) guru kelas harus tahu bahwa usia sekolah dasar menjadi tahap yang penting dalam tahap perkembangan anak ${ }^{1}$.

Berdasrkan pengamatan peneliti bahwa, dijenjang SD umumnya belum adaguru bimbingan dan konseling yang khusus menagani dan melaayani kegiatan bimbingan dan konseling bagi anak, namun demikian sesuai dengan tinkat perkembangan peserta didik usia sekolah dasar, kebutuhan akan pelayanan bimbingan dan konseling sangat dibutuhkan meskipun kenyataannya belum adanya guru bimbingan dan konseling. Walaupu layanan konseling ada namun berbeda dari kinerja konselor di jenjang sekolah menegah dan jenjang perguruan tinggi. Dengan kata lain, konselor juga dapat berperan serta secara produltif di jenjang sekolah dasar, guru kelas dapat memposisikan diri sebagai guru BK dikelas dengan yang menjadi tanggung jawabnya dengan teknik-teknik yang menyenangkan seperti permainan.

Perkembangan sosial anak sangat dipengaruhi oleh proses perlakuan atau bimbingan orang tua anak dalam mengenalkan berbagai aspek kehidupan sosial atau norma-norma kehidupan sosial, serta mendorong dan memberi contoh kepada anak tentang bagaimana menerapkan norma-norma tersebut dalam kehidupan sehari-hari. kehidupan atau proses ini disebut sosialisasi² ${ }^{2}$

Bimbingan kelompok merupakan suatu pemberian bantuan (Bimbingan) yang diberikan kepada peserta didik melalui kegiatan kelompok. Dalam layanan Bimbingan kelompok, aktivitas dan dinamika kelompok harus diwujudkan untuk membahas berbagai hal yang berguna bagi pemecahan masalah siswa yang menjadi peserta layanan.

Secara umum layanan Bimbingan kelompok merupakan layanan yang memungkinan peserta didik (masing-masing anggota kelompok) memperoleh kesempatan untuk pembahasan dan pengentasan permasalahan pribadi melalui dinamika kelompok ${ }^{3}$. Asumsi yang dipakai dalam penelitian ini adalah bahwa dalam Bimbingan kelompok akan terjadi proses interaksi antar individu, saling terbuka dan mau mengemukakan masalahnya. Belajar menemukan makna, dalam suasana kelompok, individu tidak hanya memperhatikan dirinya sendiri, dia juga bisa mendengar, melihat, dan merasakan bagaimana perasaan orang lain dalam menghadapi suatu permasalahan atau situasi tertentu dalam kehidupannya.

Teknik yang dapat diterapkan dalam layanan Bimbingan kelompok, adalah teknik umum dan permainan kelompok ${ }^{4}$.Permainan merupakan salah satu teknik dalam layanan Bimbingan kelompok baik sebagai pelengkap teknik-teknik yang lain maupun sebagai suatu teknik tersendiri yang merupakan wahana pemuat materi pembinaan atau materi layanan tertentu.

Permainan merupakan teknik yang sesuai untuk dapat mengembangkan penyesuaian sosial. Karena teknik permainan menciptakan suatu suasan santai dan menyenangkan dan akan membuat anak dapat belajar dengan lebih baik. Seperti penelitian yang dilakukan ${ }^{5}$. Membuktikan penggunaan

\footnotetext{
${ }^{1}$ Dink Meyer dan Caldwell, dalam Furqon, Konsep dan Aplikasi Bimbingan Konseling di Sekolah Dasar

2 Syamsu Yusuf, 2006. Perkembangan Anak dan Remaja: Bandung. PT. Rineka Cipta

${ }^{3}$ Amti, Erman dan Prayitno. 2004. Layanan bimbingan dan konseling kelompok. Padang: Jurusan Bimbingan dan Konseling Fakultas Ilmu Pendidikan Universitas Negeri Padang.

4 Tohirin, 2007, Bimbingan Konseling di Sekolah dan Madrasah, Jakarta: Raja Grafindo Persada

${ }^{5}$ Kurniati, Euis. 2006. Program Bimbingan untuk Mengembangkan Keterampilan Sosial Anak Melalui Permainan
} 
permainan dalam Bimbingan dapat mengembangkan penyesuaian sosial. Menurut Cremer \& Siregar tahun 1993 tingkah laku seseorang dalam permainan sama dengan tingkah lakunya dalam kehidupan sehari-hari, misalnya mengenai cara untuk mengambil keputusan, memecahkan masalah, merencanakan sesuatu dan berkomunikasi. Sehingga dapat disimpulkan dengan permainan yang diberikan, pendidik atau konselor dapat digunakan untuk mengetahui tingkah laku siswa atau peserta didik yang sebenarnya, yang dapat membantu memudahkan proses pengembangan penyesuaian sosial mereka.

Penelitian lain dilakukan oleh Dewi Arum ${ }^{6}$ Terapi bermain Gestalt (Gestalt Play Therapy) mengacu pada teknik psikoterapi yang menggunakan prinsip-prinsip dan teknik-teknik terapi Gestalt dalam penggunaan terapi bermain dengan anak. Dengan mengembangkan hubungan terapeutik tersebut, anak memperoleh kesempatan untuk mengekspresikan perasaannya, baik secara verbal ataupun non-verbal, kemudian meningkatkan kepercayaan dirinya, yang merupakan langkah penting untuk mengembangkan ekspresi emosi dan mencapai perkembangan yang optima

Penelitian Yeni Rahmawati "Pengaruh Penerapan Bimbingan Kelompok Model Permaian Pengembangan Diri Terhadap Kecenderungan Rasa Tidak Percaya Diri Siswa Kelas 1-6 di SMA Negeri 1 Jombang", dalam hasil penelitian quasi eksperimen menunjukan bahwa pengunaan teknik permainan dalam bimbingan kelompok efektif untuk meningkatkan percaya diri siswa menjadikan rekomendasi oleh para guru BK. Penggunaan permainan tradisional pada bimbingan kelompok juga mampu mengdekatkan hubungan persahabatan antar siswa, yang secara tidak langsung akan memudahkan siswa dalam melakukan penyesuaian sosial di lingkungan barunya. Bimbngan kelompok dengan permainan tradisional juga mempunyai keunggulan sebagai sarana untuk meningkatkan kemampuan beradaptasi sosial dan melatih mental siswa untuk mengatasi perilaku minder, malu dan minder, serta melatih siswa untuk lebih percaya diri dalam bermain. kemampuan mereka..

Penyesuaian sosial dapat diidentifikasikan sebagai keberhasilan seseorang dalam menyesuaikan diri dengan orang lain pada umumnya dan kelompok pada khususnya. Penyesuaian sosial merupakan kemampuan siswa untuk beradaptasi dengan lingkungan keluarga, sekolah, mata pelajaran, teman sebaya dan guru? ${ }^{7}$.

Anak yang ditolak oleh kelompok sebayanya merupakan hal yang sangat mengecewakan. Penyesuaian diri terhadap guru muncul karena dalam perkembangannya anak ingin memutuskan keterikatan dengan orang tua dan ingin mencari orang dewasa lain yang menjadi teman atau pembimbing. Anak yang tidak memiliki kemampuan beradaptasi dengan baik, bisa mengalami ketidakpuasan diri dan akan memiliki sikap penolakan diri, anak yang mengalami perasaan tersebut akan merasa dikucilkan. Akibatnya, mereka tidak merasakan kebahagiaan dalam berinteraksi dengan teman

Tradisional. Tesis. PPB FIP UPI: tidak diterbitkan.

${ }^{6}$ Dewi Arum Widhiyanti Metra Putri. 2014. Gestalt Play Therapy Untuk Menangani Masalah Penyesuaian Sosial: Studi Kasus Pada Siswa Taman Kanak-Kanak. Seminar Nasional Riset Inovatif II. Jurusan Bimbingan Konseling, Universitas Pendidikan Ganesha, Singaraja, Bali.

${ }^{7}$ Hurlock. B. Elizabeth. (1978). Perkembangan Anak. (Alih bahasa: dr. Med. Meitasari Tjandrasa dan Dra. Muslichah Zarkasih). Erlangga. 
sebaya, guru, dan keluarga.

Indikator dalam menentukan penyesuaian sosial yang dikemukan oleh Harlock diantaranya ada empat yaitu: (1) Penampilan nyata melalui sikap dan perilaku nyata (overt performance ) Perilaku sosial individu sesuai dengan standar kelompok atau memenuhi harapan kelompok, maka individu akan diterima sebagai anggota kelompok; (2) Adaptasi terhadap berbagai kelompok Individu dapat beradaptasi dengan baik pada berbagai kelompok, baik kelompok sebaya maupun kelompok dewasa; (3) Sikap sosial. Individu dapat menunjukkan sikap yang menyenangkan terhadap orang lain, terhadap partisipasi sosial dan terhadap perannya dalam kelompok maka individu tersebut akan beradaptasi dengan baik secara sosial; dan (4) Kepuasan pribadi. Individu harus dapat menyesuaikan diri dengan baik secara sosial, individu harus merasa puas terhadap kontak sosialnya dan terhadap peran yang yang dimainkannya dalam situasi sosial.

Kegiatan studi pendahuluan yang dilakukan di SDN Kedondong 1 menunjuukan bahwa terdapat beberapa anak yang didapati memiliki sikap yang menunjukkan penyesuaian sosialnya rendah, yakni tidandai dengan sikap anak yang rendah diri, dan cenderung bersikap malladaptif untuk memperoleh perhatian dari guru ataup temannya.

Temtu saja permaslahan ini harus segera diatasi, agar tidak terjadi masalah yang berlarut sehingga menghambat tercapainya tugas perkembangan peserta didik di sekolah tersbut. Salah satu alternative yang digunakan adalah pelaksanaan layanan bimbingan kelompok dengan menggunakan teknik permainan tradisional. Hal ini dipilih karena Permainan merupakan teknik yang sesuai untuk dapat mengembangkan penyesuaian sosial. Karena teknik permainan menciptakan suatu suasan santai dan menyenangkan dan akan membuat anak dapat belajar dengan lebih baik. Hal ini sejalan dengan penelitian yang dilakukan oleh Elly Fajarwatu (www.nasimaedu.com) antara lain: Santrock (1995) mengemukakan "Permainan adalah suatu bentuk penyesuaian diri manusia yang sangat berguna untuk menolong, dimana penyesuaian diri akan sangat berpengaruh pada keterampilan sosial anak.

Ada banyak jenis permainan yang dapat digunakan dalam dinamika kelompok. Secara umum, kita dapat mengklasifikasikan jenis-jenis kelompok menjadi dua jenis permainan, yaitu permainan modern dan permainan tradisional. Permainan modern mahal dan rentan terhadap masalah, yang mengarah pada pemikiran untuk memperkenalkan siswa pada jenis permainan tradisional dengan lebih baik.

Permainan tradisional memiliki kelebihan dibandingkan permainan modern, permainan tradisional yang diberikan kepada anak-anak banyak memberikan nilai-nilai pendidikan, antara lain gerak-gerik yang dibawakan, tembang yang dinyanyikan dan lagu-lagunya. Selain itu, permainan tradisional juga dapat memberikan rasa senang sebagai stimulus untuk mengembangkan keterampilan sosial siswa. Kelebihan permainan tradisional adalah mengutamakan kelompok dan kebersamaan, sederhana, memiliki nilai filosofis perilaku dan nilai sosial. Selanjutnya, permainan tradisional tidak dapat dipisahkan dari fungsi psikologis perkembangan anak, tidak hanya memberikan rasa senang, tetapi juga mengembangkan fungsi kognitif, psikomotor, sosial dan emosional anak yang ditonjolkan sebagai kontak sosial dengan teman sebaya dan penyesuaian sosial. 
Penelitian ini memiliki tujuan diantaranya (1) mengetahui pelaksanaan bimbingan bimbingan kelompok dan tingkat penyesuaian sosial siswa kelas ISDN Kedondong 01, (2) mengetahui keefektifan bimbingan kelompok dengan permaian tradisional untuk meningkatkan penyesuaian sosial siswakelas ISDN Kedondong 01.

Inilah yang menjadi dasar peneliti meneliti pengaruh layanan bimbingan kelompok dengan teknik permainan tradisional dalam meningkatkan Penyesuaian Sosial Siswa SDN Kedondong 01.

\section{Metode}

Desain penelitian ini menggunakan one group pretest-posttest design. Menurut Sugiyono ${ }^{8}$, uji keefektifan dalam desain one group pretest-posttest design adalah dengan membandingkan hasil pretest dan posttest satu kelompok subyek penelitian saja tanpa ada kelompok pembanding.

Kegiatan penelitian dilakukan oleh peneliti sebanyak enam kali pertemuan. Setiap pertemuan berlangsung kurang lebih 30 sampai 40 menit. Pertemuan pertama berisi tentang pembinaan hubungan dan penetapan kesepakatan temporal selanjutnya dan kegiatan selanjutnya. Pada pertemuan selanjutnya pelaksanaan kegiatan orientasi kelompok dipimpin oleh ketua kelompok dengan membuat permainan yang telah dijelaskan dan disepakati yaitu gobak sodor, fortifikasi dan jamur yang dibagi dalam beberapa pertemuan. Di akhir setiap kegiatan, setelah setiap pertemuan, para anggota kelompok diajak untuk melakukan refleksi atas apa yang telah dilakukan. Di akhir setiap sesi kegiatan, ketua kelompok meminta anggota untuk mengungkapkan perasaan merekaSubjek uji coba dalam penelitian ini adalah siswa kelas Iyang diambil dengan teknik purposive sampling. Teknik purposive sampling yaitu teknik pengumpulan sample dengan pertimbangan tertentu ${ }^{8}$.

Dalam teknik ini peneliti mengambil sampel yang berbeda sesuai dengan tujuan penelitian, sampel yang diambil adalah siswa yang memiliki indikator adaptasi sosial yang rendah. Terdapat 8 siswa yang memiliki nilai adaptasi sosial rendah, sehingga 8 siswa digunakan sebagai subjek penelitian

Instrumen pengumpul data yang digunakan dalam bentuk skala psikologis, panduan wawancara, pedoman observasi dan instrument validasi.

Teknik analisis data dalam penelitian pada tahap ini dilakukan secara kuantitatif. Prosedur kuantitatif dilakukan dengan menghitung persentase tingkat kecocokan sosial siswa. Untuk mengetahui keefektifan orientasi kelompok dengan teknik permainan tradisional dalam meningkatkan adaptasi sosial siswa digunakan uji beda rata-rata (tes) antara data pre-test dan post-test. Uji-t dilakukan untuk menguji perubahan-perubahan yang terjadi akibat perlakuan peneliti terhadap sampel dan untuk membandingkan skor pre-test dan post-test.. ${ }^{9}$

\section{Hasil dan Pembahasan}

Bimbingan kelompok dengan teknik permainan tradisional untuk meningkatkan penyesuaian social siswa, yang ada di SDN Kedondong 1 menunjukkan: (1) Pelaksnaan bimbingan kelompok di SDN

\footnotetext{
${ }^{87}$ Sugiyono, Metode Penelitian Kuantitatif Kualitatif dan RD (Bandung: Alfabeta, 2011), 111.
} 
Kedondong 1 sangat jarang dilaksanakan; (2) Faktor-faktor yang menghambat pelaksanaan bimbingan kelompok diantaranya: (a) Tidak ada tim ahli bimbingan dan konseling di SDN Kedondong 01; (b) pelaksana kegiatan bimbingan dan konseling adalah guru kelas yang mendapat arahan dari Guru BK yang sifatnya konselor kunjung; (c) tidak ada program yang terstruktur pada kegiatan bimbingan dan konseling. Kondisi Penyesuaian sosial peserta didik diantaranya: beberapa siswa menunjukkan sikap yang rendah diri, dan cenderung melakkan kegiatan-kegiatan yang memancing perhatian guru dan teman-temannya, sehingga anak mengalami maslah dalam bersosialisasi. Terdapat 8 anak yang mengalami masalah sosial dari 21 anak kelas 1 SDN Kedondong 1, sekitar 38\% anak memiliki penyesuaian sosial yang rendah, 5 siswa atau sekitar $24 \%$ siswa memiliki tingkat penyesuaian sosial tinggi dan selebihnyasekitar dan $38 \%$ lebihnya memiliki tingkat penyesuaian sosial sedang.

Kegiatan dalam bimbingan kelompok yang dilaksakan di SDN Kedondong 1 ini mengacu pada penelitian yang sudah dikembangkan oleh peneliti terdahulu dengan materi topic sebagai berikut:

Tabel 1.1 Tahap Permainan Dan Tujuan ${ }^{9}$

\begin{tabular}{|c|c|c|}
\hline Kegiatan & Materi/Topik & Tujuan \\
\hline $\begin{array}{l}\text { Pertemuan I } \\
\text { "Permainan Engklek" }\end{array}$ & $\begin{array}{l}\text { Bersikap menerima dan kemampuan } \\
\text { menghargai serta menghormati } \\
\text { terhadap orang yang patut dihormati } \\
\text { di sekolah } \\
\text { "Sikap menerima dan menghargai } \\
\text { orang lain" }\end{array}$ & $\begin{array}{l}\text { Siswa dibantu dalam memahami } \\
\text { kekuatan dan kelemahan diri } \\
\text { sendiri dan orang lain yang } \\
\text { berhubungan dengan penyesuaian } \\
\text { sosial. }\end{array}$ \\
\hline $\begin{array}{l}\text { Pertemuan II } \\
\text { "Permainan Cublak- } \\
\text { cublak suweng" }\end{array}$ & $\begin{array}{l}\text { Mengadakan hubungan yang sehat } \\
\text { "Mengenal Pribadi sendiri dan orang } \\
\text { lain" }\end{array}$ & $\begin{array}{l}\text { Siswa dibantu agar menghargai dan } \\
\text { menjaga rasa hormat kepada guru } \\
\text { dan staf sekolah dengan menjaga } \\
\text { komunikasi yang baik. }\end{array}$ \\
\hline $\begin{array}{l}\text { Pertemuan III } \\
\text { "Permainan jeg- } \\
\text { jegan/Bentengan" } \\
\text { Pertemuan VI } \\
\text { Permainan Gobag } \\
\text { Sodor" }\end{array}$ & $\begin{array}{l}\text { Menyesuaikan terhadap peraturan } \\
\text { "Pribadi yang pandai bergaul dan taat } \\
\text { aturan" }\end{array}$ & $\begin{array}{l}\text { Siswa dibantu untuk dapat } \\
\text { menerima prestasi baik menang } \\
\text { maupun kalah serta sadar akan } \\
\text { pentingnya tata tertib/peraturan } \\
\text { sekolah. }\end{array}$ \\
\hline $\begin{array}{l}\text { Pertemuan V } \\
\text { "Permainan Kucing- } \\
\text { kucingan" } \\
\text { Pertemuan VI } \\
\text { "Permainan } \\
\text { Jetungan/Delikan" }\end{array}$ & $\begin{array}{l}\text { Berpartisipasi aktif dalam aktivitas } \\
\text { sekolah } \\
\text { "Meningkat minat dan partisipasi } \\
\text { dalam kegiatan di sekolah" }\end{array}$ & $\begin{array}{l}\text { Membantu siswa agar mereka } \\
\text { memiliki motivasi yang kuat dan } \\
\text { bertanggung jawab dan aktif pada } \\
\text { kegiatan di sekolah }\end{array}$ \\
\hline
\end{tabular}

Pelaksanan kegiatan experiment dilakukan dengan tahapan a. Persiapan: (1) menetapkan waktu dan tujuan; (2) menyiapkan peralatan yang diperlukan; b. Pembentukan: (1) Menyampaikan salam dan doa sesuai agama masing-masing; (2) penerimaan terhadap anggota kelompok dengan hangat dan terbuka; (3) membuat presentasi; (4) menjelaskan tujuan Ketua Kelompok; (5) menjelaskan pelaksanaan

\footnotetext{
${ }^{9}$ Yunita Dwi Setyoningsih. 2012. Model Bimbingan Kelompok Teknik Permainan Berbasis Nilai Lokal Untuk Meningkatkan Penyesuaian Sosial: Tesis:Unnes
} 
bimbingan kelompok; (6) menjelaskan prinsip-prinsip pedoman dalam pelaksanaan Panduan Kelompok; (7) permainan untuk keakraban; c. Transisi terdiri dari: (1) menjelaskan kembali secara singkat bagaimana melakukan konseling kelompok; (2) melakukan tanya jawab untuk memastikan aktivitas anggota; (3) menekankan prinsip-prinsip yang dipedomani dan diperhatikan dalam layanan bimbingan kelompok; d. Kegiatannya terdiri dari: (1) menjelaskan topik atau masalah yang diangkat; (2) meminta setiap kelompok memiliki sikap keterbukaan terhadap masalah yang dihadapinya masing-masing; (3) mendiskusikan masalah yang paling banyak muncul. dan. Terminasi terdiri dari: (1) menjelaskan bahwa kegiatan orientasi kelompok akan berakhir; (2) penyampaian kemajuan yang dibuat oleh masing-masing kelompok; (3) penyampaian komitmen untuk merahasiakan urusan teman; (4) menyetuji kegiatan selanjutnya; (5) mengucapkan terima kasih; (6) berdoa menurut agama masing-masing; (7) berjabat tangan serta mengucapkan kesan masing-masing.

Berdasarkan hasil experiment lapangan didapatkan bahwa pelaksanaan bimbingan kelompok dengan teknik bermain tradisional untuk meningkatkan penyesuaian sosial, terjadi peningkatan antara sebelum dan sesudah pelaksanaan bimbingan kelompok. Atau terdapat perubahan yang signifikan antara pre-test dan post-test yang ditandai dengan peningkatan skor rata-rata sebesar 38\%, perbandingan peningkatan skor tersebut dapat dilihat pada tabel di bawah ini:

Tabel 1.2

Perbandingan Tingkat Penyesuaian Sosial Siswa pada Kondisi Awal (Pree Test) dan Kondisi

Akhir (Post Test)

\begin{tabular}{|c|l|c|c|c|c|}
\hline No & Indikator penyesuaian sosial & $\begin{array}{c}\text { Pree- } \\
\text { test }\end{array}$ & $\begin{array}{c}\text { Post- } \\
\text { tes }\end{array}$ & Perubahan & \multicolumn{1}{|c|}{ Keterangan } \\
\hline 1 & $\begin{array}{l}\text { Penampilan asli seseorang } \\
\text { berupa sikap dant tingkah laku, } \\
\text { perilaku sosial individu sesuai } \\
\text { dengan harapan kelompok dan } \\
\text { membuat peserta didik } \\
\text { diterima dikelompok tersebut }\end{array}$ & $60 \%$ & $76 \%$ & $16 \%$ & $\begin{array}{l}\text { Kenaikan penyesuaian } \\
\text { sosial pada aspek 1 terjadi } \\
\text { kenaikan sebesar 21\% }\end{array}$ \\
\hline 2 & $\begin{array}{l}\text { Penyesuaian diri terhadap } \\
\text { kelompok, peserta didik dapat } \\
\text { menyesuaikan diri dalam } \\
\text { berbagai kelompk baik } \\
\text { kelompok anak-anak maupun } \\
\text { kelompok dewasa. }\end{array}$ & $61 \%$ & $71 \%$ & $10 \%$ & $\begin{array}{l}\text { Kenaikan penyesuaian } \\
\text { sosial pada aspek 2 terjadi } \\
\text { kenaikan sebesar 17\% }\end{array}$ \\
\hline 3 & $\begin{array}{l}\text { Sikap sosial yang } \\
\text { menunjukkan sikap } \\
\text { menyenangkan terhadap orang } \\
\text { lain, partisipasi sosial, serta } \\
\text { terhdap perannya dalam } \\
\text { kelompok }\end{array}$ & $59 \%$ & $72 \%$ & $11 \%$ & $\begin{array}{l}\text { Kenaikan penyesuaian } \\
\text { sosial pada aspek 3 terjadi } \\
\text { kenaikan sebesar 21\% }\end{array}$ \\
\hline 4 & $\begin{array}{l}\text { Kepuasan pribadi, dimana } \\
\text { peserta didik dapat } \\
\text { menyesuaikan diri dengan baik } \\
\text { secara sosial, merasa nyaman } \\
\text { dan puas terhadap kontak } \\
\text { sosialnya dengan teman dan }\end{array}$ & $50 \%$ & $61 \%$ & $11 \%$ & $\begin{array}{l}\text { Kenaikan penyesuaian } \\
\text { sosial pada aspek 4 terjadi } \\
\text { kenaikan sebesar 15\% }\end{array}$ \\
\hline
\end{tabular}




\begin{tabular}{|l|l|l|l|l|l|}
\hline $\begin{array}{l}\text { terhadap peran yang dimainkan } \\
\text { dalam berbagai situasi sosial }\end{array}$ & & & & \\
\hline
\end{tabular}

\section{Penutup}

Berdasarkan paparan yang telah dijelaskan sebelumnya, maka dapat diambil beberapa kesimpulan diantaranya: 1) Pelaksanaan layanan bimbingan kelompok siswa yang selama ini terjadi di SDN Kedondong 01 sudah dilaksanakan di sekolah, namun pelaksanaan itu belum maksimal, sehingga target sasaranpun belum bisa tercapai dengan baik hanya bersifat insidental.

Hasil nilai probabilitas lebih kecil dari $0,05(0,001 \&$ lt; 0,05$)$ yang berarti bahwa hasil akhir penelitian menunjukkan bahwa terdapat perbedaan/perubahan peningkatan penyesuaian sosial siswa antara sebelum dan setelah mengikuti bimbingan kelompok dengan teknik permainan tradisional. Bimbingan kelompok dengan Permainan tradisional. Dengan demikian dapat dikatakan bahwa bimbingan kelompok dengan permainan tradisional efektif dalam meningkatkan penyesuaian sosial siswa.

\section{Daftar Rujukan}

Amti, Erman dan Prayitno. Layanan bimbingan dan konseling kelompok. Padang: Jurusan Bimbingan dan Konseling Fakultas Ilmu Pendidikan Universitas Negeri Padang. 2004.

Arum Widhiyanti Metra Putri, Dewi. Gestalt Play Therapy Untuk Menangani Masalah Penyesuaian Sosial: Studi Kasus Pada Siswa Taman Kanak-Kanak. Seminar Nasional Riset Inovatif II. Jurusan Bimbingan Konseling, Universitas Pendidikan Ganesha, Singaraja, Bali. 2014.

Dwi Setyoningsih, Yunita . Model Bimbingan Kelompok Teknik Permainan Berbasis Nilai Lokal Untuk Meningkatkan Penyesuaian Sosial. Tesis. BK Unnes: Tidak diterbitkan. 2012.

Furqon. Konsep dan Aplikasi Bimbingan Konseling di Sekolah Dasar, Bandung: Pustaka Bani Quraisy, 2005.

Kurniati, Euis. Program Bimbingan untuk Mengembangkan Keterampilan Sosial Anak Melalui Permainan Tradisional. Tesis. PPB FIP UPI: tidak diterbitkan. 2006

Rahmawati, Yeni. "Pengaruh Penerapan Bimbingan Kelompok Teknik Permainan Pengembangan Diri Terhadap Kecenderungan Tngkat Percaya Diri Siswa Kelas 1-6 SMA Negeri 1 Jombang. Skipsi. Tidak Diterbitkan. UNESA University Press, 2004.

Romlah, Tatiek. Teori dan Praktek Bimbingan Kelompok, Surabaya: Universitas Negeri Malang, 2006. Sugiyono, Metode Penelitian Kuantitatif Kualitatif dan RD, Bandung: Alfabeta, 2011.

-------, Metode Penelitian Bisnis, Bandung: CV Alfabeta, 2009.

Surya, Moh. dan Rochman Natawidjaya. Pengantar Bimbingan dan Penyuluhan, Jakarta: Universitas Terbuka, 2008.

Tohirin. Bimbingan Konseling di Sekolah dan Madrasah, Jakarta: Raja Grafindo Persada. 2007.

Wijaya, Juhana. Psikologi Bimbingan, Bandung: PT Eresco, 2008.

Syamsu, Yusuf. Perkembangan Anak dan Remaja: Bandung. PT. Rineka Cipta. 2006 